\title{
Traditional knowledge of medicinal plants used by the Chakhesang Naga tribe in Phek District of Nagaland, India
}

\author{
Nelia Lea ${ }^{1}$ and Limasenla \\ Department of Botany, Nagaland University, Lumami-798627, Nagaland \\ ${ }^{1}$ Corresponding author: E-mail: nelly12lea@gmail.com
}

[Received 12.10.2020; Revised 21.12.2020; Accepted 22.12.2020; Published 31.12.2020]

\begin{abstract}
The present paper deals with the Chakhesang Naga traditional knowledge of medicinal plants which are used for the treatment of various ailments and diseases. The paper reports 68 species belonging to 41 families and 66 genera. The ethnobotanical data were analyzed through informant consensus factor (ICF) and fidelity level (FL). The informant consensus factor shows that blood pressure $(0.87)$ has the highest agreement, followed by dermatological problems and inflammation and pain (0.83 respectively). Saccharum officinarum has the highest FL value (100\%). Leaves were the most commonly used plant part.
\end{abstract}

Key words: Medicinal plants, Chakhesang Naga tribe, Nagaland, Informant Consensus Factor, Fidelity Level

\section{INTRODUTION}

The state of Nagaland situated in Northeast India harbors rich biodiversity and is situated within the Indo-Burma Biodiversity Hotspot as recognized by IUCN. The Naga tribes have a rich knowledge, based on their natural resources of traditional folk medicine which they have developed through their age long, trial-and-error methods. The culture and traditional knowledge has been passed on from generation to generation through oral folklore, tradition, customs, and festivals. The state has 14 officially recognized Naga Tribes and 5 recognized Scheduled Tribes. Each tribe is unique from others in their rich culture and traditional practices.

Chakhesang tribe is a recognized Naga tribe, inhabiting the Phek district of Nagaland. Phek is located in the south-eastern part of Nagaland with an area of $2026 \mathrm{~km}^{2}$; is bounded by Kohima district in the West, Zunheboto and Kiphire districts in the North, Manipur state in the South and Myanmar in the South-East. The district lies between $25^{\circ} 37^{\prime} \mathrm{N}-25^{\circ} 39^{\prime} \mathrm{N}$ latitude and $94^{\circ} 35^{\prime} \mathrm{E}-94^{\circ} 38^{\prime} \mathrm{E}$ longitude. The altitude ranges from 520 to $2900 \mathrm{~m}$ above mean sea level. Phek is blessed with evergreen sub-tropical and temperate coniferous forests supporting varied flora and fauna. The district is very rich in agro-biodiversity and is well known for the production of different types of fruits and vegetables. The Chakhesangs are settled agriculturalist and practices both terrace and wet paddy field cultivation. They are also considered as best terrace makers.

During the previous decades a good number of research works on medicinal plants of the North-Eastern region of India have been contributed (Bhattacharjee et al. 1980; Bora 1999; Borthakur 1981; Borthakur \& Goswami 1995; Lokho 2012; Salam et al. 2009; Tag et al. 2008; Tiwari et al. 2009). Quite a few valuable accounts have been contributed from the state of Nagaland too (Changkija 1999; Changkija et al. 2010; Imchen \& Jamir 2011; Jamir 1997; Jamir \& Rao 1990; Jamir et al. 2008; Jamir \& Tsurho 2017; Lanusunep \& Jamir 2010; Rongsensashi et al. 2013; Sangtam et al. 2012; Singh et al. 2015), yet there is still a lot of work to do on the ethnomedicinal aspects in different parts of the state. Thus, the present work is an attempt to assess and study the traditional knowledge of medicinal plants of the Chakhesang Naga tribe. 


\section{MATERIALS AND METHODS}

At the beginning, mandatory PIC was taken from the village chiefs. The information, concerning the uses of medicinal plants for treatment of various diseases and ailments were collected during field trips from 42 local respondents, including 28 males and 14 females, comprising of the local medicine men, village elders, women folks, and hunters. The informants were between $25-90$ years of age. The plant specimens collected were physically identified by the respondents and noted of their medicinal values. Plants were then scientifically identified with the help of literature and adjacent flora such as Flora of Assam (Kanjilal et al. 1934 -1940), Flora of Jowai (Balakrishnan 1981, 1983), and Forest Flora of Meghalaya (Haridasan \& Rao 1985, 1987). The specimens were mounted and preserved following the standard procedure (Jain \& Rao 1977) and have been deposited in the Herbarium of the Department of Botany, Nagaland University, Lumami.

Based on the information obtained from the local informants the ailments were grouped into 8 categories (Table 2) viz., dermatological problems, fever, blood pressure, gastrointestinal problem, eyes \& ears, inflammation and pain, urological and urino-genital problem and others.

\section{Quantitative analysis}

The ethnobotanical data obtained was analyzed using different quantitative tools such as Informant Consensus Factor (ICF) and Fidelity Level (FL).

\section{Informant Consensus Factor (ICF)}

ICF value was used to see the homogeneity in the information given by the informants. It is calculated by using the formula (Trotter \& Logan 1986; Heinrich et al. 1998):

$$
\mathrm{ICF}=\frac{\text { Nur }-\mathrm{Nt}}{\text { Nur }-1}
$$

Where $\mathrm{N}_{\mathrm{ur}}$ is the number of use reports for each disease category and $\mathrm{N}_{\mathrm{t}}$ is the number of species used to treat the particular category. The factor provides a range between 0 to 1 , where the high value indicates a higher rate of informant consensus.

\section{Fidelity Level (FL)}

The fidelity level (FL) determines the most frequently used plant species to treat a particular ailment of the study area. FL is calculated by using the formula (Friedman et al. 1986):

$$
\mathrm{FL}(\%)=\frac{\mathrm{Np}}{\mathrm{N}} \times 100
$$

Where $\mathrm{N}_{\mathrm{p}}$ is the number of informants that claim the use of a plant species for particular treatment and $\mathrm{N}$ is the total number of informants that use the plant for any disease.

\section{RESULT AND DISCUSSION}

The present survey recorded 68 species of plants those are used by the Chakhesang tribe of Nagaland for treating various ailments in their day to day life. In the enumeration, the plant species are arranged alphabetically along with their family and local names followed by the part(s) used and the medicinal uses (Table 1).

Of 68 species of medicinal plants, 66 genera and 41 families has been recorded. Except Equisetum ramosissimum, a pteridophyte, all others are angiospermic. Herbs were the primary source of medicine (57\%), followed by trees $(22 \%)$, shrubs $(17 \%)$ and climbers $(4 \%)$. Most of the plant species collected from the wild were used both as vegetables. Some species were also planted in their kitchen gardens. The most dominant family of the present study is Asteraceae (10 spp.), followed by Lamiaceae (6 spp.), and Solanceae (5 spp). Based on the informants, the 
Table 1. Medicinal plants used by the Chakhesang Naga tribe of Nagaland

\begin{tabular}{|c|c|c|c|}
\hline $\begin{array}{c}\text { Botanical name [Family]; Voucher } \\
\text { specimen }\end{array}$ & $\begin{array}{l}\text { Local } \\
\text { name }\end{array}$ & $\begin{array}{c}\text { Part/s } \\
\text { used }\end{array}$ & Medicinal uses \\
\hline $\begin{array}{l}\text { Abelmoschus moschatus Medik. } \\
\text { [Malvaceae]; NL - } 198\end{array}$ & Muli & Bark & $\begin{array}{l}\text { Bark is crushed and used as hair wash for } \\
\text { smooth hair and relieve from dandruff. }\end{array}$ \\
\hline $\begin{array}{l}\text { Ageratina adenophora (Spreng.) } \\
\text { R.M.King \& H.Rob. [Asteraceae]; NL-193 }\end{array}$ & Japanpru & Leaf & $\begin{array}{l}\text { Leaf paste is applied to cuts and wounds } \\
\text { as haemostatic }\end{array}$ \\
\hline $\begin{array}{l}\text { Ageratum conyzoides (L.)L. [Asteraceae]; } \\
\text { NL-194 }\end{array}$ & Pru & Leaf & $\begin{array}{l}\text { Leaf paste is applied to cuts and wounds } \\
\text { as haemostatic. }\end{array}$ \\
\hline $\begin{array}{l}\text { Allium sativum L. [Amaryllidaceae]; NL- } \\
131\end{array}$ & Shamure & Bulb & $\begin{array}{l}\text { Bulb is taken orally for high blood } \\
\text { pressure; helps in digestion; stomach- } \\
\text { ache; relieve flatulence; it is also used as } \\
\text { febrifuge. }\end{array}$ \\
\hline $\begin{array}{l}\text { Alnus nepalensis D.Don } \\
\text { [Betulaceae]; NL-296 }\end{array}$ & Pasii & $\begin{array}{l}\text { Bark } \\
\text { and leaf }\end{array}$ & $\begin{array}{l}\text { Bark is soaked in water overnight and the } \\
\text { infusion is taken for diabetes; leaf paste is } \\
\text { applied to foot sores. }\end{array}$ \\
\hline $\begin{array}{l}\text { Artemisia indica Willd. [Asteraceae]; NL- } \\
144\end{array}$ & Apre & Leaf & $\begin{array}{l}\text { Leaf paste is applied to cuts and wounds } \\
\text { as haemostatic; for skin infection; the } \\
\text { fresh plant is also used as insect repellent. }\end{array}$ \\
\hline Bidens pilosa L. [Asteraceae]; NL-108 & Richavu & $\begin{array}{l}\text { Whole } \\
\text { plant }\end{array}$ & $\begin{array}{l}\text { Plant is boiled in water and the decoction } \\
\text { taken orally for fever and stomach-ache; } \\
\text { leaf paste is applied on skin disease. }\end{array}$ \\
\hline $\begin{array}{l}\text { Brugmansia suaveolens (Willd.) Bercht. \& } \\
\text { J. Presl [Solanaceae]; NL-183 }\end{array}$ & Abvo & Leaf & $\begin{array}{l}\text { Leaf is warmed in fire and } \\
\text { applied/dabbed to body ache, muscle } \\
\text { pain and sprain. }\end{array}$ \\
\hline $\begin{array}{l}\text { Cajanus cajan (L.) Millsp. [Leguminosae]; } \\
\text { NL- } 137\end{array}$ & $\begin{array}{l}\text { Mukri } \\
\text { motoshi }\end{array}$ & Leaf & $\begin{array}{l}\text { The decoction of the leaves is taken in } \\
\text { jaundice and for gall bladder. }\end{array}$ \\
\hline $\begin{array}{l}\text { Cannabis sativa L. [Cannabaceae]; NL- } \\
179\end{array}$ & Ganjapru & Leaf & $\begin{array}{l}\text { Leaf paste is applied to cuts and wounds } \\
\text { as haemostatic; leaves boiled in water and } \\
\text { the mixture is used for treating muscle } \\
\text { pain and sprain; leaf paste is also used as } \\
\text { antidote for snake bite. }\end{array}$ \\
\hline $\begin{array}{l}\text { Capsicum annum L. [Solanaceae]; NL- } \\
141\end{array}$ & Mushishi & Fruit & $\begin{array}{l}\text { Fruit aids in removing or eliminates fever } \\
\text { and stimulate appetite; fruit paste is used } \\
\text { for rheumatism }\end{array}$ \\
\hline $\begin{array}{l}\text { Centella asiatica (L.) Urb. [Apiaceae]; } \\
\text { NL-145 }\end{array}$ & Revu & $\begin{array}{l}\text { Whole } \\
\text { plant }\end{array}$ & $\begin{array}{l}\text { Whole plant is taken raw or boiled in } \\
\text { water for gastric problem; consumed as } \\
\text { blood purifier, and subdue dysentery. }\end{array}$ \\
\hline $\begin{array}{l}\text { Clerodendrum colebrookeanum Walp. } \\
\text { [Lamiaceae]; NL-133 }\end{array}$ & Piduvu & Leaf & $\begin{array}{l}\text { Leaf is boiled in water and taken for high } \\
\text { blood pressure; decoction of leaf is taken } \\
\text { as tonic; use as antipyretic. }\end{array}$ \\
\hline $\begin{array}{l}\text { Colocasia esculenta (L.) Schott [Araceae]; } \\
\text { NL-147 }\end{array}$ & $B i$ & Stem & $\begin{array}{l}\text { Stem sap is applied to bee sting and insect } \\
\text { bites. }\end{array}$ \\
\hline $\begin{array}{l}\text { Crassocephalum crepidioides (Benth.) S. } \\
\text { Moore [Asteraceae]; NL-175 }\end{array}$ & Ava tabvo & Leaf & $\begin{array}{l}\text { Leaf paste is applied to cuts and wounds } \\
\text { as haemostatic }\end{array}$ \\
\hline $\begin{array}{l}\text { Curculigo capitulata (Lour.) Kuntze } \\
\text { [Molineria capitulata (Lour.) Herb.] } \\
\text { [Hypoxidaceae]; NL-180 }\end{array}$ & $\begin{array}{l}\text { Tukho } \\
\text { convi }\end{array}$ & Root & $\begin{array}{l}\text { Root extract is used in eye and ear } \\
\text { problem. }\end{array}$ \\
\hline
\end{tabular}




\begin{tabular}{|c|c|c|c|}
\hline $\begin{array}{c}\text { Botanical name [Family]; Voucher } \\
\text { specimen }\end{array}$ & $\begin{array}{l}\text { Local } \\
\text { name }\end{array}$ & $\begin{array}{c}\text { Part/s } \\
\text { used }\end{array}$ & Medicinal uses \\
\hline $\begin{array}{l}\text { Debregeasia longifolia Wedd. } \\
\text { [Urticaceae]; NL-225 }\end{array}$ & Melibo & $\begin{array}{l}\text { Bark, } \\
\text { fruit }\end{array}$ & $\begin{array}{l}\text { The bark is crushed and used as } \\
\text { shampoo; the fruit aids in digestion. }\end{array}$ \\
\hline $\begin{array}{l}\text { Elaeocarpus floribundus Blume } \\
\text { [Elaeocarpaceae]; NL-375 }\end{array}$ & Tishi & Fruit & $\begin{array}{l}\text { Fruit is taken for blood pressure and } \\
\text { nausea. }\end{array}$ \\
\hline $\begin{array}{l}\text { Elsholtzia blanda (Benth.) Benth. } \\
\text { [Lamiaceae]; NL-537 }\end{array}$ & Khronve & Leaf & $\begin{array}{l}\text { The decoction of leaf is used for treating } \\
\text { hypertension and diarrhoea. }\end{array}$ \\
\hline $\begin{array}{l}\text { Entada rheedei Spreng. } \\
\text { [Leguminosae]; NL-248 }\end{array}$ & Zali & Seed & $\begin{array}{l}\text { The cotyledon is used as soap and also } \\
\text { used as vegetable. }\end{array}$ \\
\hline $\begin{array}{l}\text { Equisetum ramosissimum D.Don } \\
\text { [Equisetaceae]; NL-168 }\end{array}$ & Abou & $\begin{array}{l}\text { Whole } \\
\text { plant }\end{array}$ & $\begin{array}{l}\text { The decoction of the plant is taken orally } \\
\text { to treat kidney problem and urinary tract } \\
\text { infection. }\end{array}$ \\
\hline $\begin{array}{l}\text { Gynura bicolor (Roxb. ex Willd.) DC. } \\
\text { [Asteraceae]; NL-109 }\end{array}$ & Tabovu & $\begin{array}{l}\text { Leaf, } \\
\text { young } \\
\text { stem }\end{array}$ & $\begin{array}{l}\text { Tender aerial part of the plant is boiled in } \\
\text { water and taken orally for gastritis, } \\
\text { stomach-ache, and constipation. }\end{array}$ \\
\hline $\begin{array}{l}\text { Hellenia speciosa (J.Koenig) S.R.Dutta } \\
\text { [Cheilocostus speciosus (J.Koenig) C.D.Specht] } \\
\text { [Costaceae]; NL-191 }\end{array}$ & Rhamabi & $\begin{array}{l}\text { Rhizome } \\
\text { leaf }\end{array}$ & $\begin{array}{l}\text { Rhizome paste is used in rheumatism. } \\
\text { Decoction of the leaf is taken for diabetes } \\
\text { and urinary problems. }\end{array}$ \\
\hline $\begin{array}{l}\text { Hibiscus sabdariffa L. [Malvaceae]; NL- } \\
163\end{array}$ & Khrevu & $\begin{array}{l}\text { Leaf, } \\
\text { sepal }\end{array}$ & $\begin{array}{l}\text { Fresh as well as dried leaves and sepals is } \\
\text { boiled and taken as a stimulant, for high } \\
\text { blood pressure and to treat veisalgia. }\end{array}$ \\
\hline Hibiscus syriacus L. [Malvaceae]; NL-111 & $\begin{array}{l}\text { Menapan } \\
\text { yi }\end{array}$ & Leaf & $\begin{array}{l}\text { The decoction of the leaf is taken for } \\
\text { menstrual problem. }\end{array}$ \\
\hline $\begin{array}{l}\text { Houttuynia cordata Thunb. } \\
\text { [Saururaceae]; NL-178 }\end{array}$ & Sama & $\begin{array}{l}\text { Whole } \\
\text { plant }\end{array}$ & $\begin{array}{l}\text { The whole plant is consumed raw or } \\
\text { cooked to treat diarrhoea, stomach-ache; } \\
\text { blood pressure. }\end{array}$ \\
\hline Juglans regia L. [Juglandaceae]; NL-295 & Khushi & $\begin{array}{l}\text { Bark, } \\
\text { fruit }\end{array}$ & $\begin{array}{l}\text { The inner layer of the bark is used to treat } \\
\text { gum bleeding and tooth plague. The bark } \\
\text { and unripe fruit is used as fish poison. }\end{array}$ \\
\hline $\begin{array}{l}\text { Justicia adhatoda L. [Acanthaceae]; NL- } \\
246\end{array}$ & Kekipa & Leaf & $\begin{array}{l}\text { Leaves boiled with water and massage to } \\
\text { relieve body ache. }\end{array}$ \\
\hline $\begin{array}{l}\text { Kalanchoe pinnata (Lam.) Pers. } \\
\text { [Crassulaceae]; NL-135 }\end{array}$ & Lotsitse & Leaf & $\begin{array}{l}\text { The decoction of the leaf is taken for } \\
\text { kidney problem. }\end{array}$ \\
\hline $\begin{array}{l}\text { Laggera crispata (Vahl) Hepper \& J.R.I } \\
\text { Wood [Asteraceae]; NL-251 }\end{array}$ & Khana & $\begin{array}{l}\text { Leaf, } \\
\text { inflores } \\
\text { cence }\end{array}$ & $\begin{array}{l}\text { The inflorescence and leaves are made } \\
\text { into paste and applied over skin infection; } \\
\text { the leaves are crushed and applied for } \\
\text { piles problem. }\end{array}$ \\
\hline $\begin{array}{l}\text { Leucosceptrum canum Sm. [Lamiaceae]; } \\
\text { NL-155 }\end{array}$ & Chutupu & $\begin{array}{l}\text { Leaf, } \\
\text { inflores } \\
\text { cence }\end{array}$ & $\begin{array}{l}\text { The white tomentum is scrap from the } \\
\text { leaves and applied as haemostatic; } \\
\text { inflorescence is soaked in water and the } \\
\text { infusion taken as a tonic. }\end{array}$ \\
\hline $\begin{array}{l}\text { Litsea cubeba (Lour.) Pers. [Lauraceae]; } \\
\text { NL-158 }\end{array}$ & Tirashi & Fruit & $\begin{array}{l}\text { It is used as a carminative and stimulant; } \\
\text { fruit also taken as spices. }\end{array}$ \\
\hline
\end{tabular}


Nelia Lea \& Limasenla

\begin{tabular}{|c|c|c|c|}
\hline $\begin{array}{c}\text { Botanical name [Family]; Voucher } \\
\text { specimen }\end{array}$ & $\begin{array}{l}\text { Local } \\
\text { name }\end{array}$ & $\begin{array}{c}\text { Part } / \mathrm{s} \\
\text { used }\end{array}$ & Medicinal uses \\
\hline $\begin{array}{l}\text { Lobelia nummularia Lam. } \\
\text { [Campanulaceae]; NL-172 }\end{array}$ & Murusako & $\begin{array}{l}\text { Whole } \\
\text { plant }\end{array}$ & $\begin{array}{l}\text { The decoction of the plant is used for } \\
\text { urinary infection; leaf paste is used to stop } \\
\text { bleeding. }\end{array}$ \\
\hline $\begin{array}{l}\text { Maesa indica (Roxb.) Sweet } \\
\text { [Myrsinaceae]; NL-215 }\end{array}$ & Rhavu & Leaf & $\begin{array}{l}\text { Leaves are consumed directly to get } \\
\text { instant energy from fatigue. }\end{array}$ \\
\hline Melia azedarach L. [Meliaceae]; NL-391 & Thosiibu & Leaf & $\begin{array}{l}\text { Leaves are boiled in water and bath for } \\
\text { treating skin disease. }\end{array}$ \\
\hline Mentha arvensis L. [Lamiaceae]; NL-132 & Pubupru & $\begin{array}{l}\text { Leaf, } \\
\text { young } \\
\text { stem }\end{array}$ & $\begin{array}{l}\text { Leaves are taken raw or boiled for } \\
\text { stomach-ache and as a carminative. }\end{array}$ \\
\hline $\begin{array}{l}\text { Mimosa pudica L. [Leguminosae]; NL- } \\
134\end{array}$ & Nuovipru & $\begin{array}{l}\text { Root } \\
\text { and leaf }\end{array}$ & $\begin{array}{l}\text { Roots and leaves decoction is used to } \\
\text { treat leucorrhoea, urinary problem; leaf } \\
\text { paste is applied on skin infections. }\end{array}$ \\
\hline Musa paradisiaca L. [Musaceae]; NL-124 & Vii & $\begin{array}{l}\text { Stem } \\
\text { and } \\
\text { fruit }\end{array}$ & $\begin{array}{l}\text { Stem is sliced and soak in water overnight } \\
\text { and the infusion is taken orally for kidney } \\
\text { problem; fruit is taken to subdue } \\
\text { diarrhoea. }\end{array}$ \\
\hline $\begin{array}{l}\text { Nicotiana tabacum L. [Solanaceae]; NL- } \\
187\end{array}$ & $\begin{array}{l}\text { Makhruv } \\
\text { u }\end{array}$ & Leaf & $\begin{array}{l}\text { The leaves are crushed and mixed in } \\
\text { water and used as pesticides for cultivated } \\
\text { vegetable; leaf paste is haemostatic; } \\
\text { relieves rheumatic swelling; it is also used } \\
\text { as a laxative. }\end{array}$ \\
\hline $\begin{array}{l}\text { Ocimum basilicum L. [Lamiaceae]; NL- } \\
104\end{array}$ & Nepiu & $\begin{array}{l}\text { Leaf, } \\
\text { inflores } \\
\text { cence }\end{array}$ & $\begin{array}{l}\text { Leaves and inflorescence are taken raw or } \\
\text { boiled in water for fever, stomach-ache, } \\
\text { carminative, heartburn. }\end{array}$ \\
\hline $\begin{array}{l}\text { Oxalis corniculata L. [Oxalidaceae]; NL- } \\
107\end{array}$ & $\begin{array}{l}\text { Natume } \\
\text { muta }\end{array}$ & $\begin{array}{l}\text { Whole } \\
\text { plant }\end{array}$ & $\begin{array}{l}\text { The decoction of the plant is taken to } \\
\text { treat diarrhoea. Leaf juice is used to } \\
\text { remove warts, treat wounds and eczema; } \\
\text { leaves are crushed and used to wash latex } \\
\text { or sap stains from hands. }\end{array}$ \\
\hline Paederia foetida L. [Rubiaceae]; NL-345 & Theburo & Leaf & $\begin{array}{l}\text { Leaf extract is applied to ease ear pain; } \\
\text { leaf juice is taken for diarrhoea, dysentery. }\end{array}$ \\
\hline $\begin{array}{l}\text { Passiflora edulis Sims } \\
\text { [Passifloraceae]; NL-182 }\end{array}$ & Stabon & Leaf & $\begin{array}{l}\text { Leaves are boiled in water and taken for } \\
\text { high blood pressure and diabetes. }\end{array}$ \\
\hline $\begin{array}{l}\text { Phyllanthus emblica L. [Phyllanthaceae]; } \\
\text { NL-728 }\end{array}$ & Rhoshi & Fruit & $\begin{array}{l}\text { Fruits eaten to treat cough, cold and high } \\
\text { blood pressure; stimulate appetite; blood } \\
\text { purifier. Juice extracted from raw fruit is } \\
\text { applied to treat eye infection. }\end{array}$ \\
\hline $\begin{array}{l}\text { Plantago asiatica subsp. erosa (Wall.) } \\
\text { Z.Yu Li [Plantaginaceae]; NL-110 }\end{array}$ & $\begin{array}{l}\text { Dzuvu } \\
\text { pavu }\end{array}$ & $\begin{array}{l}\text { Whole } \\
\text { plant }\end{array}$ & $\begin{array}{l}\text { Plant is boiled in water and taken for } \\
\text { stomach-ache, dysentery and kidney } \\
\text { problem; leaf paste applied to cuts and } \\
\text { wounds. }\end{array}$ \\
\hline $\begin{array}{l}\text { Prunus persica (L.) Batsch [Rosaceae]; } \\
\text { NL-123 }\end{array}$ & Krishi & Leaf & Leaf paste is applied to ring worm. \\
\hline Psidium guajava L. [Myrtaceae]; NL-127 & Muduram & $\begin{array}{l}\text { Leaf } \\
\text { and } \\
\text { fruit }\end{array}$ & $\begin{array}{l}\text { Tender leaves are taken raw or decoction } \\
\text { of the leaf is taken for stomach-ache, } \\
\text { diarrhoea and dysentery. Fruit is also } \\
\text { consumed for subduing diarrhoea. } \\
\text { Leaves are chewed for toothache. }\end{array}$ \\
\hline
\end{tabular}




\begin{tabular}{|c|c|c|c|}
\hline $\begin{array}{c}\text { Botanical name [Family]; Voucher } \\
\text { specimen }\end{array}$ & $\begin{array}{l}\text { Local } \\
\text { name }\end{array}$ & $\begin{array}{c}\text { Part/s } \\
\text { used }\end{array}$ & Medicinal uses \\
\hline Punica granatum L. [Lythraceae]; NL-138 & Radushi & Leaf & Leaf decoction is taken in fever \& typhoid \\
\hline $\begin{array}{l}\text { Ranunculus diffusus DC. } \\
\text { [Ranunculaceae]; NL-174 }\end{array}$ & Achuthib & $\begin{array}{l}\text { Whole } \\
\text { plant }\end{array}$ & $\begin{array}{l}\text { The aerial part is crushed and applied to } \\
\text { wounds. }\end{array}$ \\
\hline $\begin{array}{l}\text { Rhododendron arboreum Sm. } \\
\text { [Ericaceae]; NL-428 }\end{array}$ & Dupa & Flower & $\begin{array}{l}\text { Dried or fresh petal is used in removal of } \\
\text { fish bone from throat. }\end{array}$ \\
\hline $\begin{array}{l}\text { Rhus chinensis Mill. [Anacardiaceae]; NL- } \\
254\end{array}$ & $M v u$ & Fruit & $\begin{array}{l}\text { Decoction of fruit is used in indigestion, } \\
\text { colic, vomiting, hypertension and allergy. } \\
\text { It is also a detoxifier. }\end{array}$ \\
\hline $\begin{array}{l}\text { Ricinus communis L. [Euphorbiaceae]; } \\
N L-113\end{array}$ & Midziïpru & Leaf & $\begin{array}{l}\text { Leaf warmed over fire or in hot water is } \\
\text { massaged to relieve muscle pain, sprain \& } \\
\text { body-ache; leaf paste is applied on sores }\end{array}$ \\
\hline $\begin{array}{l}\text { Rubia sikkimensis Kurz [Rubiaceae]; NL- } \\
217\end{array}$ & Elhi & $\begin{array}{l}\text { Whole } \\
\text { plant }\end{array}$ & $\begin{array}{l}\text { The decoction of the plant is taken for } \\
\text { urinary problem. }\end{array}$ \\
\hline Rubus ellipticus Sm. [Rosaceae]; NL-430 & Ramushe & $\begin{array}{l}\text { Bark of } \\
\text { shoot \& } \\
\text { root }\end{array}$ & $\begin{array}{l}\text { The decoction of root and shoot bark is } \\
\text { used for stomach-ache. }\end{array}$ \\
\hline $\begin{array}{l}\text { Saccharum officinarum L. [Poaceae]; } \\
\text { NL-117 }\end{array}$ & $\begin{array}{l}\text { Muk:hrup } \\
\text { ru }\end{array}$ & Culm & $\begin{array}{l}\text { Juice is used as demulcent, and taken in } \\
\text { jaundice, gall bladder problem. }\end{array}$ \\
\hline $\begin{array}{l}\text { Scutellaria discolour Colebr. [Lamiaceae]; } \\
\text { NL-307 }\end{array}$ & Rucie nha & Leaf & The decoction of leaf is used in malaria. \\
\hline $\begin{array}{l}\text { Senecio scandens Buch.-Ham. ex D.Don } \\
\text { [Asteraceae]; NL-421 }\end{array}$ & $\begin{array}{l}\text { Mhubi } \\
\text { nha }\end{array}$ & Leaf & Leaf extract is used for eye treatment. \\
\hline Solanum indicum L. [Solanaceae]; NL-142 & Akhashi & Fruit & $\begin{array}{l}\text { Fruit is taken raw or boiled for high blood } \\
\text { pressure; fever; asthma; flatulence. }\end{array}$ \\
\hline $\begin{array}{l}\text { Solanum myriacanthum Dunal } \\
\text { [Solanaceae]; NL-148 }\end{array}$ & $\begin{array}{l}\text { Kekathits } \\
\text { be }\end{array}$ & Fruit & Fruit is used for toothache. \\
\hline $\begin{array}{l}\text { Sonchus wightianus DC. [Asteraceae]; } \\
\text { NL-195 }\end{array}$ & Gazu & $\begin{array}{l}\text { Aerial } \\
\text { part }\end{array}$ & $\begin{array}{l}\text { The aerial part is boiled with water and } \\
\text { taken for treatment of kidney problem } \\
\text { and high blood pressure. }\end{array}$ \\
\hline $\begin{array}{l}\text { Spilanthes paniculata Wall. ex DC. } \\
\text { [Asteraceae]; NL-751 }\end{array}$ & Vevu & $\begin{array}{l}\text { Aerial } \\
\text { part }\end{array}$ & $\begin{array}{l}\text { Inflorescence is crushed and applied to } \\
\text { subdue toothache; decoction of the plant } \\
\text { is used in abdominal pain. }\end{array}$ \\
\hline $\begin{array}{l}\text { Spondias pinnata (L.f.) Kurz } \\
\text { [Anacardiaceae]; NL-128 }\end{array}$ & Muzqaoshi & Fruit & $\begin{array}{l}\text { Fruit is taken for high blood pressure and } \\
\text { vomiting. }\end{array}$ \\
\hline $\begin{array}{l}\text { Swertia bimaculata Hook.f. \& Thomson } \\
\text { ex C.B. Clarke [Gentianaceae]; NL-103 }\end{array}$ & Akha-pru & $\begin{array}{l}\text { Stem, } \\
\text { leaf }\end{array}$ & $\begin{array}{l}\text { Aerial part of the plant is boiled in water } \\
\text { and taken for gastritis and fever. }\end{array}$ \\
\hline $\begin{array}{l}\text { Tainia viridifusca (Hook.) Benth. \& } \\
\text { Hook.f. [Orchidaceae]; NL-384 }\end{array}$ & Kopa & Tuber & $\begin{array}{l}\text { The fleshy tuber is crushed and applied to } \\
\text { heal crack heel. }\end{array}$ \\
\hline $\begin{array}{l}\text { Thalictrum foliolosum DC. } \\
{[\text { Ranunculaceae]; NL-312 }}\end{array}$ & Tehapru & Root & $\begin{array}{l}\text { The roots are boiled in water and taken to } \\
\text { treat fever, malaria and typhoid. }\end{array}$ \\
\hline Urtica dioica L. [Urticaceae]; NL-201 & Angu & Leaf & $\begin{array}{l}\text { Fresh leaves are crushed and paste is } \\
\text { applied to treat mumps and scabies. }\end{array}$ \\
\hline $\begin{array}{l}\text { Zanthoxylum armatum DC. [Rutaceae]; } \\
\text { NL-475 }\end{array}$ & Ngachu & $\begin{array}{l}\text { Leaf, } \\
\text { fruit }\end{array}$ & $\begin{array}{l}\text { Soup of leaf/fruit with garlic and chilly is } \\
\text { taken to reduce fever; fruit is used as } \\
\text { carminative, subdue toothache. }\end{array}$ \\
\hline $\begin{array}{l}\text { Zingiber officinale Roscoe } \\
\text { [Zingiberaceae]; NL-130 }\end{array}$ & Vou & Rhizome & $\begin{array}{l}\text { Decoction of rhizome is taken for cough; } \\
\text { cold and sore throat; carminative; paste } \\
\text { used for rheumatism; urinary problems. }\end{array}$ \\
\hline
\end{tabular}


most cited species are Allium sativum, Gynura bicolor and Phyllanthus emblica (23), Capsicum annum (22), Alnus nepalensis, Equisetum ramosissimum and Juglans regia (21), Centella asiatica and Hibiscus sabdariffa (20), Elaeocarpus floribundus, Psidium guajava and Rhus chinensis (19), and Cannabis sativa (18).

The most prevalent ailments are blood pressure, fever, cough and cold, stomachache, cuts and wounds, muscle pain/sprain, eyes and ears problem, skin infection, and diarrhoea. The maximum number of plants reported to treat ailments against blood pressure (10), fever (9), stomachache (9), cuts and wounds (8), diarrhoea (8), skin infection (6), muscle pain (5) and kidney problem (5).

The most common part of the plant utilized for treatment is leaves $44 \%$, followed by fruits $16 \%$, whole plant $11 \%$, bark and flower $6 \%$, root and aerial part $4 \%$, stem and rhizome $3 \%$, bulb, seed and tuber $1 \%$. Usually the mode of preparation is from raw plant materials. The different methods of usage are decoction, paste, infusion, soup, extract, cooked, heat pressed, etc. Decoction is the most common method of preparation, followed by paste. The mode of application are either taken internally or applied externally. Fruits of Elaeocarpus floribundus, Phyllanthus emblica, Solanum indicum, Rhus chinensis, Spondias pinnata are consumed raw for blood pressure and is highly recommended by the local informants for the above mentioned ailments. Solanum indicum, Rhus chinensis and Spondias pinnata fruits are also taken as soup cooked along with Allium cbinensis to bring down high blood pressure and relieve from headache. The locals believe that taking Rhododendron arboreum petals either fresh or dried before sleep removes the fish bone stuck in the throat, which is an age old practice. Thus, almost every house in the village keeps dried petals of the plant. Many of the plant species were found to be used to treat cuts and wounds, and this may be due to the fact that almost all the informants are farmers and are prone to bruises.

The present study indicates a high level of consensus, the value of ICF in the study area showed the ranges from 0.77 to 0.87 . To calculate the ICF value, the ailments were grouped into 8 categories. The use report was highest for gastrointestinal problem with 139, followed by dermatological problem with 105 use report, and others with 79 use report. ICF value was highest for blood pressure with 0.87 , followed by dermatological problems and inflammation with 0.83 and fever with 0.82 (Table 2). According to the consensus factor it can be said that blood pressure is prevalent in the study area. Within the dermatological category the most common ailments was cuts and wounds (47), and in gastrointestinal category the most reported ailment was stomach-ache (44).

Fidelity level (FL) indicates the informants choice of plant species in each disease category. For the analysis the plants mentioned once was not considered. The FL of plant species in the study area ranged from 25 to $100 \%$ (Table 3). Saccharum officinarum showed $100 \%$ FL against jaundice. Psidium guajava, Gynura bicolor, Phyllanthus emblica, Zingiber officinale, Allium sativum, indicated $69.6 \%, 78.9 \%, 69.6 \%, 66.7 \%, 60.9 \%$ FL against diarrhoea, gastritis, hypertension, cough and cold, fever respectively.

Artemisia indica is used as hemostats and insect repellant by the Chakhesang tribes, whereas, the dried plant is burnt and smoke is inhaled to treat sinusitis and headache by the villagers of Humla district of Western Nepal (Rokaya et al. 2010). The infusion of the bark of Juglans regia is use for oral care (Rokaya et al. 2010) which is also used for the similar purpose by the Chakhesang tribe. Justicia adhatoda is used for the treatment of pneumonia and cough by the Reang tribes (Shil et al. 2014) where as it is used chiefly for bodyache by the Chakhesangs. Allium sativum root is used to treat warts and rheumatism by the people of Tlanchinol, Hidalgo, Mexico (Andrade-Cetto 2009) which is extensively used to treat hypertension by the Chakhesangs. Leaf juice of Senecio scandens is use for eye treatment by the Chakhesang tribe whereas; the same is given to treat asthma, gastritis and skin disease by the ethnic people in Parbat district of 
Table 2. Informant Consensus Factor (IFC) by categories of diseases.

\begin{tabular}{|l|c|c|c|}
\hline \multicolumn{1}{|c|}{ Category of Diseases } & $\begin{array}{c}\text { Number of } \\
\text { use reports }\end{array}$ & $\begin{array}{c}\text { Number of } \\
\text { taxa used }\end{array}$ & ICF \\
\hline Dermatological problems (Hair, skin, cuts \& wounds) & 105 & 19 & 0.83 \\
\hline Fever (Malaria, typhoid, cough \& cold, nausea) & 82 & 15 & 0.82 \\
\hline Blood pressure & 68 & 10 & 0.87 \\
\hline $\begin{array}{l}\text { Gastrointestinal problem (Stomach-ache, gastritis, } \\
\text { diarrhoea, constipation, piles) }\end{array}$ & 139 & 29 & 0.79 \\
\hline $\begin{array}{l}\text { Eyes \& Ears problem } \\
\text { Inflammation \& Pain (Body ache, sprain, toothache, } \\
\text { mumps) }\end{array}$ & 47 & 4 & 0.77 \\
\hline Urological \& urino-genital problems & 47 & 11 & 0.83 \\
\hline $\begin{array}{l}\text { Others (Diabetes, snake bite, insect bite, veisalgia, tonic, } \\
\text { fish bone stuck in throat, pesticides) }\end{array}$ & 79 & 17 & 0.79 \\
\hline
\end{tabular}

Table 3. Fidelity Level (FL) of highly utilized medicinal plants of the study area

\begin{tabular}{|l|l|l|l|l|l|l|}
\hline S1.No & Species name & $\boldsymbol{N}_{\boldsymbol{I}}$ & $\boldsymbol{N}_{\boldsymbol{A}}$ & $\begin{array}{l}\text { Major ailment } \\
\text { treated for }\end{array}$ & $\boldsymbol{N}_{\boldsymbol{P}}$ & FL \\
\hline 1. & Allium sativum & 23 & 5 & Fever & 14 & 60.9 \\
\hline 2. & Gynura bicolor & 23 & 3 & Gastritis & 16 & 69.6 \\
\hline 3. & Phyllanthus emblica & 23 & 5 & Blood pressure & 16 & 69.6 \\
\hline 4. & Capsicum annum & 22 & 3 & Fever & 11 & 50.0 \\
\hline 5. & Juglans regia & 21 & 3 & Bleeding gum & 5 & 23.8 \\
\hline 6. & Centella asiatica & 20 & 3 & Blood purifier & 7 & 35.0 \\
\hline 7. & Hibiscus sabdariffa & 20 & 4 & Veisalgia & 5 & 25 \\
\hline 8. & Psidium guajava & 19 & 4 & Diarrhoea & 15 & 78.9 \\
\hline 9. & Rhus cbinensis & 19 & 6 & Colic & 10 & 52.6 \\
\hline 10. & Cannabis sativa & 18 & 5 & Bodyache & 7 & 38.9 \\
\hline 11. & Litsea cubeba & 18 & 3 & Carminative & 7 & 38.9 \\
\hline 12. & Artemisia indica & 17 & 3 & Wounds & 8 & 47.1 \\
\hline 13. & Passiflora edulis & 16 & 3 & Blood pressure & 8 & 50.0 \\
\hline 14. & Cheilocostus speciosus & 15 & 3 & Rheumatism & 7 & 46.7 \\
\hline 15. & Plantago major & 15 & 4 & Stomach ache & 5 & 33.3 \\
\hline 16. & Zingiber officinale & 15 & 5 & Cough \& cold & 10 & 66.7 \\
\hline 17. & Clerodendrun glandulosum & 13 & 3 & Blood pressure & 7 & 53.8 \\
\hline 18. & Oxalis corniculata & 13 & 5 & Skin problem & 4 & 30.8 \\
\hline 19. & Ricinus communis & 12 & 3 & Body ache & 6 & 50.0 \\
\hline 20. & Saccharum officinarum & 12 & 3 & Jaundice & 12 & 100 \\
\hline 21. & Bidens pilosa & 11 & 3 & Fever & 4 & 36.4 \\
\hline 22. & Mimosa pudica & 11 & 3 & Leucorrhoea & 5 & 45.5 \\
\hline
\end{tabular}

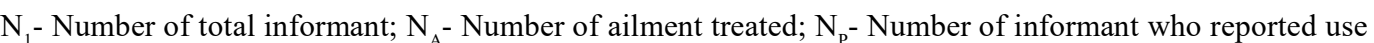
of species; FL- Fidelity level 
western Nepal (Malla et al. 2015). The infusion and decoction of whole plant of Ageratum conyzoides is used against leprosy, bone dislocation and fever by the Kel village, Neelum Valley, Azad Kashmir, Pakistan (Ahmad 2017), whereas the Chakhesang tribe uses the leaf paste chiefly as haemostat.

\section{CONCLUSION}

Present study has revealed that the traditional method of medicinal plants is still practiced by the Chakhesang tribe in spite of modernization. And the community still largely depends on the medicinal plants for treating various health issues. It has also been observed that many of the plant species have a broad spectrum for treating various diseases with the same plant. In spite of the richness of plant wealth in the area the numbers are declining every passing day due to deforestation for agricultural practices and various developmental activities. Also rampant collection of medicinal plants, especially uprooting of plants to harvest good income has led to fast decline of some valuable medicinal plants. Therefore there is an urgent need to educate, conserve, protect and manage the forest for sustainability of man and nature. There is also a pressing need to assess and document the ethnomedicinal plants for further scientific study so as to tap the plant rich resources for a vibrant healthcare product.

\section{Acknowledgements}

The authors are thankful to the local healers, village elders and all the individuals for valuable knowledge and help during the field work. The authors are also grateful to the Department of Botany, Nagaland University, for various facilities and encouragement. The first author is grateful to University Grant Commission BSR for financial assistance.

\section{LITERATURE CITED}

Ahmad, K.S.; Hamid, A.; Nawaz, F.; Hameed, M.; Ahmad, F.; Deng, J.; Akhtar, N.; Wazarat, A. and Mahroof, S. 2017. Ethnopharmacological studies of indigenous plants in Kel village, Neelum Valley, Azad Kashmir, Pakistan. Journal of Ethnobiology and Ethnomedicine 13: 68.

Andrade-Cetto, A. 2009. Ethnobotanical study of the medicinal plants from Tlanchinol, Hidalgo, Mexico. Journal of Ethnopharmacology 122: 163 - 171.

Balakrishnan, N.P. 1981 \& 1983. Flora of Jowai. Vol. I \& II, Botanical Survey of India, Howrah.

Bhattacharjee, S.; Tiwari, K.C.; Majumder, R. \& Misra, A.K. 1980. Folklore medicine from district Kamrup (Assam). Bulletin of Medico Ethnobotanical Research 1: 447 - 460.

Bora, P.J. 1999. A study on ethno-medicinal plants among the Bodo tribe of Sonitpur district of Assam. Journal of Economic and Taxonomic Botany 23(2): 609 - 614.

Borthakur, S.K. 1981. Studies in ethnobotany of Karbis (Mikirs): Plant masticatories and dyestuffs. In: S.K. Jain (Ed). Glimpse of Indian Ethnobotany. Scientific Publisher, Jodhpur, India. Pp. $180-190$.

Borthakur, S.K. \& Goswami, N. 1995. Herbal Remedies from Demoria of Kamrup district of Assam in North East India. Filoterabia 66(4): 333 - 339.

Changkija, S. 1999. Folk medicinal plants of the Nagas in India. Asian Folklore Studies, 58: 205 -230 .

Changkija, S.; Ajungla, L.; Rongsensashi \& Mozhui, R. 2010. Medicinal and Aromatic Flora of Nagaland. MPDA, Dept. of Forest, Ecology, Environment and Wildlife, Govt. of Nagaland. 
Friedman, J.; Yaniv, Z.; Dafni, A. \& Palewitch, D. 1986. A preliminary classification of the healing potential of medicinal plants, based on a rational analysis of an ethnopharmacological field survey among Bedouins in the Negev desert, Israel. Journal of Ethnopharmacology 16: 275 - 287.

Haridasan, K. \& Rao, R.R. 1985, 1987. Forest Flora of Meghalaya. Vol. I \& II, Bishen Singh Mahendra Pal Singh, Dehra Dun.

Heinrich, M.; Ankli, A.; Frei, B.; Weimann, C. and Sticher, O. 1998. Medicinal plants in Mexico: Healers' consensus and cultural importance. Social Science and Medicine. 47(11): 1859 - 1871.

Imchen, K. \& Jamir, N. S. 2011. Ethnomedicinal plants used by the Phom-Naga tribe in Longleng district of Nagaland, India. Pleione 5(1): 77 - 82.

Jain, S.K. \& Rao, R.R. 1977. A Handbook of field and Herbarium methods. In Today and Tomorrow's Printers and Publishers, New Delhi.

Jamir, H. \& Tsurho, K. 2017. Documentation of medicinal plants and its uses by Chang tribe in Tuensang District, Nagaland. Journal of Medicinal Plants Studies 5(4): 170 - 174.

Jamir, N.S. 1997. Ethnobiology of Naga tribe in Nagaland - 1. Medicinal herbs. Journal of Society of Ethno Botanists 9(1): 101 - 104.

Jamir, N.S. \& Rao, R.R. 1990. Fifty new or interesting medicinal plants used by the Zeliang of Nagaland (India). Journal of Society of Ethno Botanists 2: $11-18$.

Jamir, N.S.; Jungdan \& Madhabi, S. 2008. Traditional knowledge of medicinal plants used by the Yimchunger-Naga tribes in Nagaland. Pleione 2(2): 223 - 228.

Kanjilal, U.N.; Kanjilal, P.C.; Das, A.; De, R.N. \& Bor, N.L. 1934 - 1940. Flora of Assam. Vols. I - V, Govt. of Assam, Shillong.

Lanusunep \& Jamir N.S. 2010. Folk-medicinal herbs used by the Sumi-Naga tribe of Zunheboto district, Nagaland. Pleione 4(2): 215 - 220.

Lokho, A. 2012. The folk medicinal plants of the Mao Naga in Manipur, North East India. International Journal of Scientific Research Publication 2(6): 1 - 8.

Malla, B.; Gauchan, D.P. \& Chhetri, R.B. 2015. An ethnobotanical study of medicinal plants used by ethnic people in Parbat district of western Nepal. Journal of Ethnopharmacology 165: 103 - 117 .

Rokaya, M.B.; Munzbergova, Z. \& Timsina, B. 2010. Ethnobotanical study of medicinal plants from the Humla district of Western Nepal. Journal of Ethnopharmacology 130: 485 - 504.

Rongsensashi; Mozhui, R.; Changkija, S. \& Limasenla 2013. Medicinal plants diversity of Fakim Wildlife Sanctuary, Nagaland, India. Pleione 7(1): 110 - 126.

Salam, S.; Jamir, N.S. \& Singh, P.K. 2009. Traditional uses of medicinal plants used by the Thankul-Naga tribe in Manipur, India. Pleione 3(2): 157 - 162.

Sangtam, T.L.; Jamir, N.S.; Deb, C.R., \& Jamir, S. 2012. A Study on the Medicinal Plants Used by the Sangtam Naga Tribe in Kiphire District, Nagaland, India. International Journal of Ayurvedic And Herbal Medicine 2: 267 - 275

Shil, S.; Choudhury, M.D. \& Das, S. 2014. Indigenous knowledge of medicinal plants used by the Reang tribe of Tripura state of India. Journal of Ethnopharmacology 152: 135 - 141.

Singh, P. K.; Gajurel, P. R.; Panmei, R. \& Rethy, P. 2015. Indigenous healing practices and ethnomedicinal plants used against Jaundice by some Naga tribes in Nagaland, India. Pleione 9(1): $40-48$. 
Tag, H.; Murtem, G.; Das, A.K. \& Singh, R.K. 2008. Diversity and distribution of ethnobotanical plants used by the Adi tribe in East Siang district of Arunachal Pradesh, India. Pleione 2(1): $123-136$.

Tiwari, U.L.; Kotia, A. \& Rawat, G.S. 2009. Medico-ethnobotany of Monpas in Tawang and West Kameng districts of Arunachal Pradesh, India. Pleione 3(1): 1 - 8.

Trotter R.T. \& Logan M.H. 1986. Informant consensus: a new approach for identifying potentially effective medicinal plants In: Etkin N.L. (Ed.), Plants in Indigenous Medicine and Diet, Biobehavioural Approaches. Bedford Hills, NY: Redgrave Publishers. Pp. 91 - 112. 